to appoint a special officer, and the East India Company's botanist, Dr. William Roxburgh, held the post from 1793 until 1813. Roxburgh published his "Flora Indica", which became the basis of many subsequent Indian botanical works. In spite of a series of well-known superintendents (F. Buchanan (afterwards Hamilton), N. Wallich, W. Griffith, Hugh Falconer, T. Thomson, T. Anderson, C. B. Clarke, G. King), the Garden suffered vicissitudes of progress and serious set-backs. Cyclones practically devastated the grounds on more than one occasion, and once the Herbarium became seriously depleted through supplying other herbaria too lavishly. Recovery began under the administration of Dr. (afterwards Sir) George King, who retired in 1897 ; and still further improvements were made under Sir David Prain, who succeeded King and remained superintendent until 1905. Since that date, the Garden has continued performing important functions under the administration of several successive superintendents. The present superintendent is $\mathbf{M r}$. K. P. Biswas, who, until his recent promotion, was curator of the Garden Herbarium. For several months since relinquishing his curatorship, Mr. Biswas has been working at the Royal Botanic Gardens, Kew. The Garden lies on the right bank of the River Hooghly, at Sibpur, just outside Calcutta; and is now about 270 acres in extent. Apart from work of a 'pure' botanical nature, much work of economic importance - chiefly to India-is being pursued along lines similar to those obtaining at Kew. The authorities are to be congratulated on the Garden attaining its 150th anniversary, and Mr. Biswas on his recent appointment as superintendent.

\section{An Early Text-book of Chemistry}

THE small text-book on chemistry, "Tyrocinium Chymicum", of Jean Beguin, a native of Lorraine, was first published anonymously in 1610 and went through a large number of editions. The first issue was intended for the use of Beguin's own pupils in a school of pharmacy he established in Paris, but it was pirated and re-issued in Cologne in 1611. Beguin then re-issued it in 1612. Prof. T. S. Patterson, in a paper on "Jean Beguin and his Tyrocinium Chymicum", published in Annals of Science (2, 243298 ; 1937), has given a very full account of the various editions of the book and a description of its contents. As he says, "it is certain, on account of the large number of editions issued, that Beguin's little book was found to be of great practical value, and it must have done much in unostentatious fashion to guide real chemistry along a sound experimental path. . . Beguin was much under alchymical influence.. . but his was a commonsense alchymy and he used its philosophy in an entirely reasonable manner. There was little of the fantastic and nothing of the quack or impostor, or even of the willing dupe or self-deceiver, in him." In a preface by Barth in a later edition, it is said : "Beguin, on account of his virtue, opened his school in Paris-that celebrated emporium of all the wits, and compendium of the whole world-and did not burden his pupils and learners (for princes, counts, nobles, councillors and doctors, attracted by its novelty, meanwhile frequented his chemical laboratory) with useless and prolix comments and various descriptions of his remedies, but prepared in their sight candidly and simply, the secret medicaments of Quercetanus and others, of all kinds both solution and coagulation".

\section{Science and Mankind}

THE Manufacturing Chemist of November includes a further symposium of notes from contemporary scientific workers on "Science and Mankind". Contributions in the October number from Mr. H. G. Wells, Sir Richard Gregory, Prof. L. Hogben, Prof. H. Levy and Sir Daniel Hall are followed by others from Prof. J. B. S. Haldane, who stresses the importance of adequate organization to supply the Press with scientific news, and of thinking rationally about economics and politics, and Mr. C. S. Garland, who directs attention to the vital need for an organization which can speak for science as a whole and of the importance of having representatives in Parliament who are really concerned with the welfare of the profession as a whole. Sir Ernest Graham-Little outlines the contribution which medical science can make to improve social conditions. Dr. W. Cullen, while pointing out that the ultimate effects of a scientific or technical discovery are largely unpredictable, stresses the impossibility of stopping scientific and technical progress and, while con. demning the prostitution of science as in warfare, directs attention to the way in which social conditions have been improved by scientific and technical advances. Prof. Alfred Stock expresses the hope that the progress of chemistry and physics has rendered war so terrible that the use of brute force will be renounced by the nations in reality, and that then science will be able to devote itself completely to the welfare, health and enjoyment of existence of mankind.

\section{Research in Canada}

THE nineteenth annual report of the National Research Council of the Dominion of Canada, for the year 1935-36, refers to the valuable work of the Division of Chemistry on the utilization of Alberta's natural gas. Optimum conditions have been determined for the production of ethylene, and a method has also been developed giving three to four gallons of benzene from each thousand cubic feet of Turner Valley stabilizer gas. Reference is also made to the synthesis of a number of plant hormones and to the discovery that alkaloids of the giant larkspur, a plant growing wild in southern Alberta, are powerful insecticides. The Division of Chemistry has also developed an improved method of measuring the hiding power of paints, and the wax mixture previously developed for use in plucking chickens has now come into wide use in preparing poultry for the market. Dry-cleaning research has included the study of noninflammable cleaning solvents, such as trichloroethylene, the manufacture of which is being undertaken in Canada. The Division of Biology and Agriculture has compiled an extensive review of the 